( ) Матасар І.Т., Алексєєва Н.Г., 2019

doi: 10.37321/nefrology.2019.25-08

УДК 616.61-085.38-612.392

\title{
ОЦІНКА ХАРЧОВОГО СТАТУСУ У ХВОРИХ НА ХРОНІЧНУ ХВОРОБУ НИРОК ТА АЛІМЕНТАРНА КОРЕКЦІЯ ВСТАНОВЛЕНИХ ПОРУШЕНЬ
}

\author{
1.Т. МАТАСАР, ${ }^{2}$ Н.Г. АЛЕКСЄЄВА
}

(за матеріалами презентації доповіді на науково-практичній конференції «Нефрологія: up to date» 26 вересня 2019 р., м. Ужгород)

${ }^{1}$ ДУ “Національний науковий центр радіаційної медицини Національної академії медичних наук України", Київ

²ДУ «Інститут нефрології НАМН України», м. Київ

Резюме.

\section{Ключові слова:}

Вступ. Дана робота присвячена проблемі порушення харчування, недоїдання у пацієнтів, котрі лікуються діалізом, також були описані основні методи корекції цього порушення.

Мета. Встановити порушення харчового статусу пацієнтів, які знаходяться на замісної ниркової терапії, перитонеальному діалізі та разробити методики корекції харчового статусу.

Матеріали та методи. У пацієнтів з хронічним захворюванням нирок, яких лікують безперервним діалізом, визначають рівень калію, гемоглобіну, альбуміну і розраховують індекс маси тіла (IMT), суб'єктивну глобальну оцінку (СГО). Кореляційний аналіз був ідентифікований для того, щоб визначити частку пацієнтів з гіпокаліємією і її можливий зв'язок з гемоглобіном, альбуміном, каль-ціевофосфорним обміном, паратиреоїдного гормоном, трансферрином, рівнями феритину і IMT.

Результати. В ході обстеження було встановлено, що у пацієнтів з гіпокаліємією рівень гемоглобіну, альбуміну та IMT нижче, ніж у пацієнтів з нормальним рівнем калію в крові. Рівень трансферину, феритину, кальцій-фосфорного обміну речовин, натрію і хлориду не мав суттєвих відмінностей.

Висновки. Корекція харчового статусу хворих з нирковою недостатністю в поєднанні з оптимізацією процедур діалізу покращує якість життя хворих.

хронічна хвороба нирок, замісна ниркова терапія, стан харчування, недоїдання, білково-енергетична недостатність.

\section{Оцінка харчового статусу хворих XXН та аліментарна корекція встановлених порушень}

д.мед.наук, проф., завлаб. гігієни харчування та безпеки їжі ДУ "ННЦРМ НАМН України “

лікар-нефролог вищої категорії

ДУ "Інститут нефрології НАМН України “

Їжа є найважливішим біологічним чинником життєзабезпечення організму, вона створює вплив на ріст та здоров'я, сприяє збереженню високої працездатності, попереджає виникнення та сприяє успішному лікуванню хвороб, а також запобігає передчасному старінню, зменшує негативний вплив факторів хімічної, фізичної чи біологічної природи на людину.

Їжі, як надзвичайно складний і багатокомпонентний фактор, в залежності від збалансованості і складу раціону може впливати на функції і трофіку тканин, органів і систем організму.

Порушення статусу харчування обумовлює проблеми, що виникають у пацієнтів, які перебувають на замісній нирковій терапії чи отримують перитонеальний діаліз. 
Своєчасна діагностика розладів із наступною їх аліментарною корекцією дозволяє поліпшити віддалені ефекти лікування хворих на хронічну хворобу нирок.

\section{Слайд 2}

Харчовий статус хворих, які проходять лікування гемодіалізом оцінюється за допомогою комбінації методів

Визначення альбуміну сироватки крові;

$\square$ Встановлення відсотку від післядіалізної ваги тіла;

$\square$ Встановлення відсотку від стандартної ваги тіла (NHANES II);

$\square$ Проведення суб'єктивної глобальної оцінки;

$\square$ Встановлення стандартизованого білкового еквіваленту виведення азоту (БВА);

$\square$ Встановлення індексу маси тіла (IMT);

$\square$ Оцінка стану фактичного харчування (дієтарне інтерв'ю).

\section{Слайд 3.}

Оцінка розмірів тіла по щирині ліктя (см) дорослих пацієнтів
(дані отримані за методикою NHÁNES II)

\begin{tabular}{|c|c|c|c|}
\hline \multirow[t]{2}{*}{ Bi k } & \multicolumn{3}{|c|}{ Скелелпий розмі $р$ іл ла $n=50$} \\
\hline & Малий & Середні й & Великий \\
\hline पолові ки & $\mathbf{0}$ & $19(38 \%)$ & $7(14 \%)$ \\
\hline $35-44$ & $\leq 6,7$ & $>6,7<8,0$ & $\geq 8,0$ \\
\hline $45-54$ & $\leq 6,7$ & $>6,7<8,1$ & $\geq 8,1$ \\
\hline $55-64$ & $\leq 6.7$ & $>6,7<8,1$ & $\geq 8,1$ \\
\hline $65-74$ & $\leq 6,7$ & $>6,7<8,1$ & $\geq 8,1$ \\
\hline Жі нКИ & $1(2 \%)$ & $20(40 \%)$ & $3(6 \%)$ \\
\hline $35-44$ & $\leq 5,7$ & $>5,7<7,1$ & $\geq 7,1$ \\
\hline $55-64$ & $\leq 5,8$ & $>5,8<7,2$ & $\geq 7,2$ \\
\hline $65-74$ & $\leq 5,8$ & $>5,8<7,2$ & $\geq 7,2$ \\
\hline
\end{tabular}

Кількість чоловіків з малим розміром 0, 3 середнім 19 (38\%), 3 великим - 7 (14\%);

Кількість жінок 3 малим розміром - 1 (2\%), середнім розміром $20(40 \%)$, з великим $-3(6 \%)$.

\section{Слайд 4}

Вміст жиру в організмі обстежених пацієнтів, \% від загальної маси тіла

\begin{tabular}{|c|c|}
\hline \hline Показник & Чисельність пацієнтів \\
\hline \hline Норма: $9-24 \%$ & $33(66 \%)$ \\
\hline$>9$ & $16(32 \%)$ \\
\hline$<24$ & $16(32 \%)$ \\
\hline $\begin{array}{c}\text { При суб'єктивній глобальній оцінці за методикою NHANES } \\
\text { II у 100\% паціснтів спостерігалась втрата маси тіла до 5\% 3a } 6 \\
\text { місяців спостережень, що с нормою. }\end{array}$ \\
\hline
\end{tabular}

Стандартизований білковий еквівалент виведення азоту (БВА);

$\begin{aligned} & \text { БВА }(r / \mathrm{kr} / \text { добу })=(2,8 \times \mathrm{Co}) /(36,3+5,48 \times[\mathrm{spKt} / \mathrm{V}]+53,5] \\ & {[\mathrm{spKt} / \mathrm{V}])+0,168 }\end{aligned}$

Со - концентрація сечовини крові (ммоль/л) до сеансу гемодіалізу. spKt/V однеі пично стабільних пацієнтів БВА повинно бути не меншим 1 г/кг ідеальної маси тіла/день.

БBA $=1-48(96 \%) ; \quad$ BBA $<1-2(4 \%)$
До вашої уваги ми представляємо дані обстеження хворих, які перебувають на гемодіалізі.

\section{Слайд 5}

Переддіалізний альбумін плазми, гл

\begin{tabular}{|c|c|c|c|}
\hline \multicolumn{4}{|c|}{ Ступінь недостатності харчування } \\
\hline Норма & легкий & середній & важкий \\
\hline$>35$ & $34-30$ & $29-24$ & $<25$ \\
\hline $\mathrm{n}=50$ & не виявлено & не виявлено & не виявлено \\
\hline \multicolumn{4}{|c|}{$\begin{array}{c}\text { У } 100 \% \text { паціснтів, що проходять гемодіаліз, } \\
\text { альбумін сироватки крові в межах норми }\end{array}$} \\
\hline
\end{tabular}

\section{Слайд 5}

\section{Індекс маси тіла} (IMT)

\begin{tabular}{|c|c|c|}
\hline IMT & Порушення & $\begin{array}{c}\text { К-ть хворих, } \\
\mathrm{n}=50(\%)\end{array}$ \\
\hline$<16$ & Важке схуднення & не виявлено \\
\hline $16,0-16,99$ & Помірне схуднення & не виявлено \\
\hline $17,0-18,49$ & Легке схуднення & 1 осіб $(2 \%)$ \\
\hline 18,5-24,9 & $\begin{array}{c}\text { Межі нормальної маси } \\
\text { тіла }\end{array}$ & $33(66 \%)$ \\
\hline $25,0-29,9$ & Надмірна маса тіла & 10 осіб $(20 \%)$ \\
\hline $30,0-34,9$ & Ожиріння I ступеня & 4 осіб $(8 \%)$ \\
\hline $35-39$ & Ожиріння II ступеня & 2 осіб $(4 \%)$ \\
\hline$>4 \underline{0}$ & Ожиріння Ш ступеня & не виявлено \\
\hline
\end{tabular}

\section{Слайд 6}

Переддіалізний альбумін плазми, гл

\begin{tabular}{|c|c|c|c|}
\hline \multicolumn{4}{|c|}{ Ступінь недостатності харчування } \\
\hline Норма & легкий & середній & важкий \\
\hline$>35$ & $34-30$ & $29-24$ & $<25$ \\
\hline $\mathrm{n}=50$ & не виявлено & не виявлено & не виявлено \\
\hline \multicolumn{4}{|c|}{$\begin{array}{l}\text { У } 100 \% \text { паціснтів, що проходять гемодіаліз, } \\
\text { альбумін сироватки крові в межах норми }\end{array}$} \\
\hline
\end{tabular}


За даними нутріціології, організм людини, для збереження своїх функцій потребує щодоби приблизно 600 інгредієнтів, серед яких $66 €$ есенціальними. В цьому асортименті $€$ захисні компоненти, що зменшують ризик розвитку захворювань, сприяють лікуванню уражених органів і систем у людей, які контактують із шкідливими чинниками.

\section{Слайд 7.}

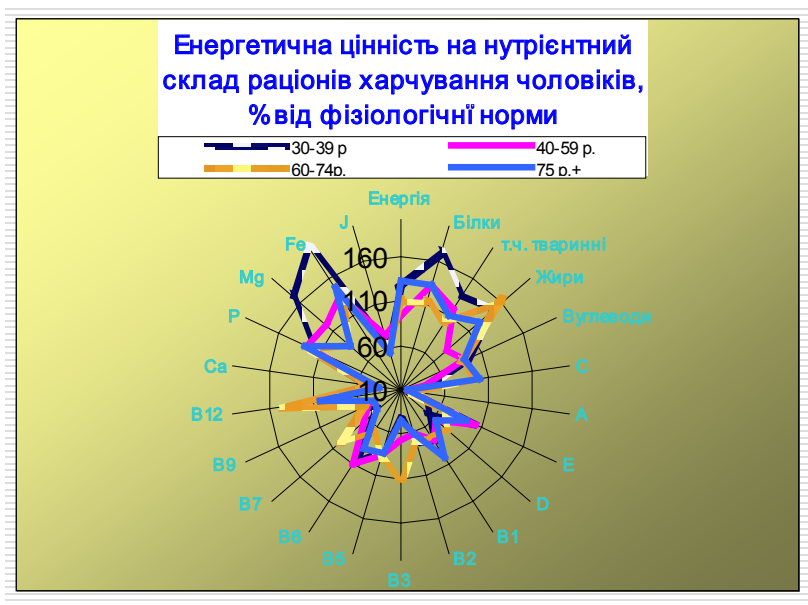

\section{Слайд 8}

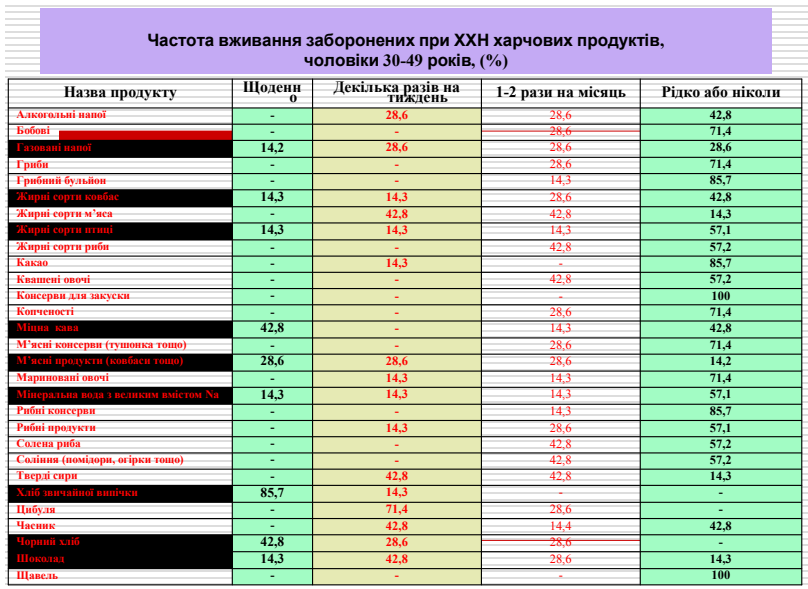

\section{Слайд 9}

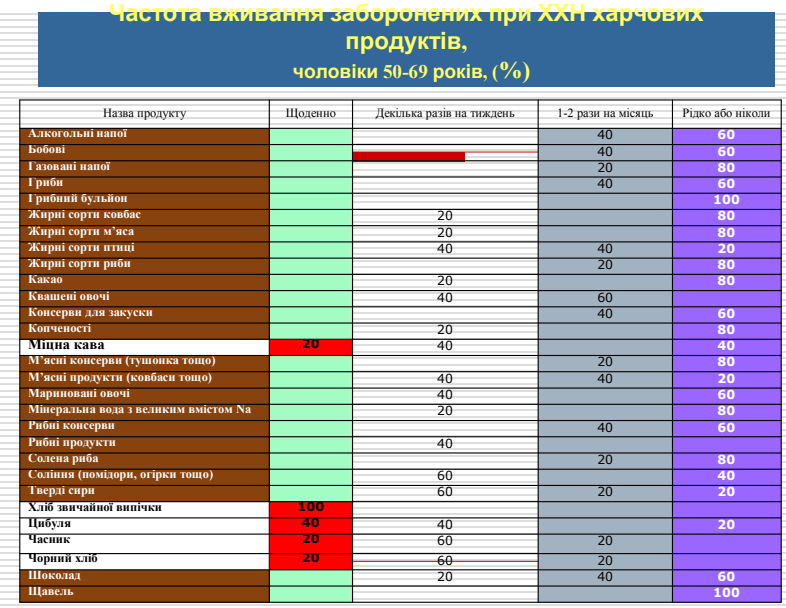

Для задоволення потреб організму, людина щотижня має споживати не менше 30 різноманітних продуктів і страв.

Результати вивчення стану фактичного харчування свідчать;

\section{Слайд 10}

Частота вживання заборонених при XXН продуктів харчування, чоловіки 70 років та старші, (\%)

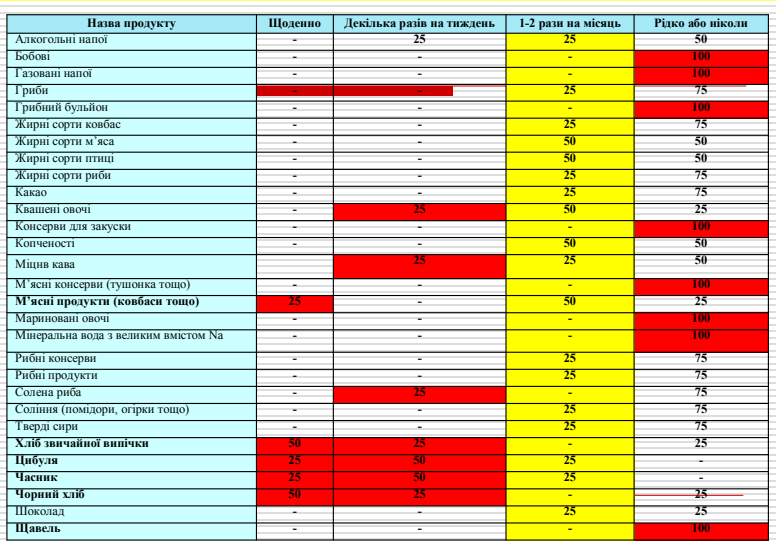

\section{Слайд 11}

\section{астота вживання рекомендованих при XXН харчових продуктів, чоловіки 30-49 років, (\%)}

\begin{tabular}{|l|c|c|c|c|}
\hline \multicolumn{1}{|c|}{ Назва продукту } & Щодено & $\begin{array}{c}\text { Декілька разів } \\
\text { натшждень }\end{array}$ & $\begin{array}{c}1-2 \text { рази на } \\
\text { місящь }\end{array}$ & $\begin{array}{c}\text { Pідко або́ } \\
\text { ніколи }\end{array}$ \\
\hline Курага & - & - & - & 100 \\
\hline Родзинки & - & 14,3 & - & $\mathbf{8 5 , 7}$ \\
\hline Салати із сирих овочів & 14,3 & 42,8 & 14,3 & $\mathbf{2 8 , 6}$ \\
\hline Салати із столової зелені & 14,3 & 28,6 & 14,3 & $\mathbf{4 2 , 8}$ \\
\hline Свіжий буряк & - & 14,3 & 28,6 & $\mathbf{5 7 , 1}$ \\
\hline Свіжий гарбуз & - & 14,3 & - & $\mathbf{8 5 , 7}$ \\
\hline Свіжий кабачок & - & 14,3 & - & $\mathbf{8 5 , 7}$ \\
\hline Свіжий огірок & 28,6 & 57,1 & - & 14,3 \\
\hline Свіжі абрикоси & - & 28,6 & 14,3 & $\mathbf{5 7 , 1}$ \\
\hline Свіжі дині & - & 14,3 & 28,6 & $\mathbf{5 7 , 1}$ \\
\hline Свіжі кавуни & 14,3 & 28,6 & 28,6 & $\mathbf{2 8 , 6}$ \\
\hline Свіжі фрукти & 28,6 & 57,1 & - & 14,3 \\
\hline Чорнослив & - & - & - & 100 \\
\hline
\end{tabular}

\section{Слайд 12}

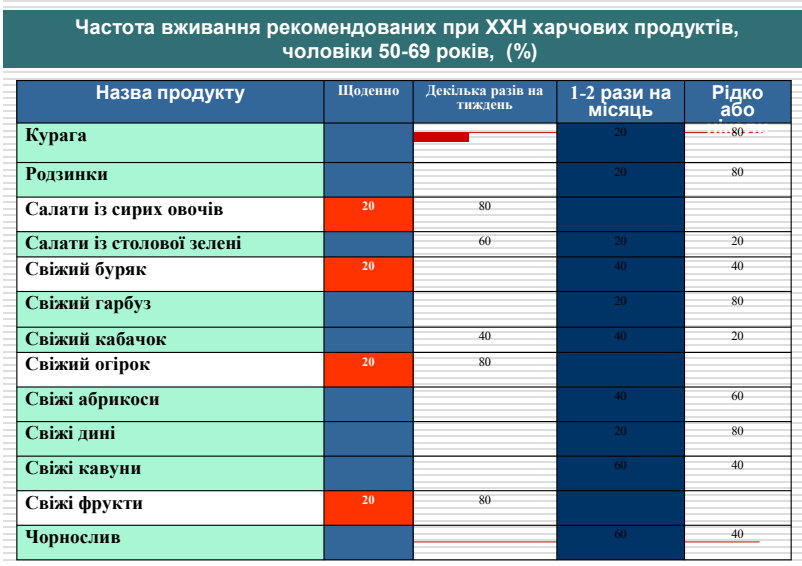




\section{Слайд 13}

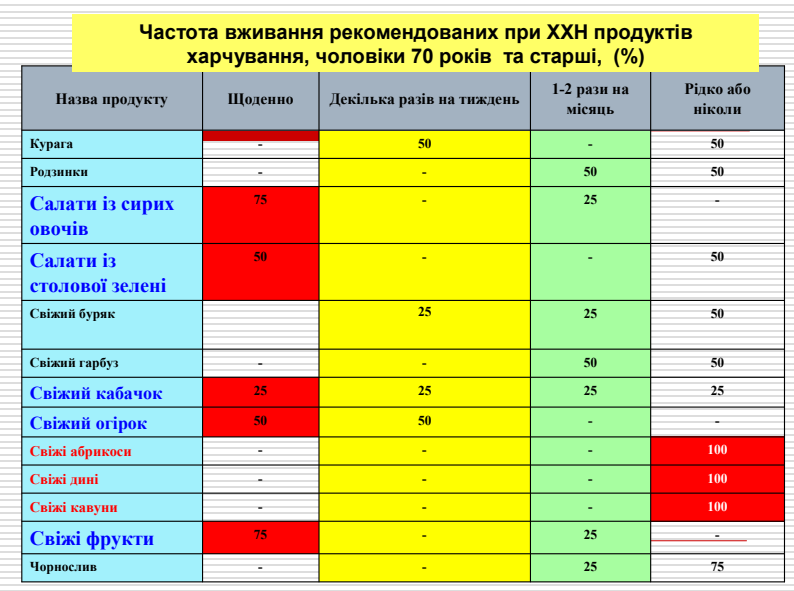

\section{Слайд 14}

Енергетична цінність та нутрієнтний склад харчових раціонів обстежених жінок, у \% від фізіологічної норми

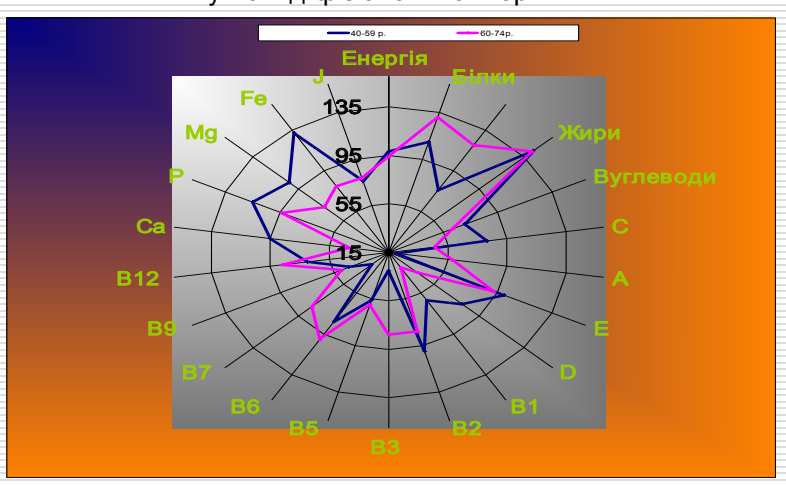

\section{Слайд 15}

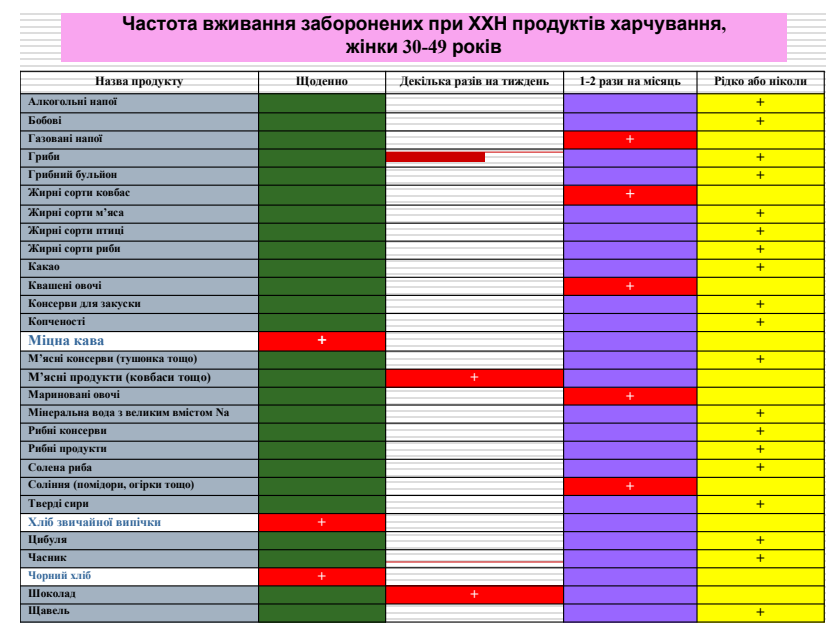

\section{Слайд 16}

Частота вживання заборонених при XXH продуктів харчування, жінки 50-69 років, (\%)

\begin{tabular}{|c|c|c|c|c|}
\hline Назва проуукту & 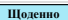 & Декіıка рахів па тикаешь & 1-2 рази иа місящь & Різко або́ піколи \\
\hline Aлкогольй ианої & $\cdot$ & - & - & 100 \\
\hline $\begin{array}{l}\text { Бобові } \\
\text { Газовані напої }\end{array}$ & $\div$ & 10 & 40 & 60 \\
\hline Гриби & & & 30 & \\
\hline Грнбиший бульйон & - & $=$ & 10 & 90 \\
\hline Жирні сорти ковб́ас & & & 50 & 50 \\
\hline Fирпі сорти м'яса & - & 10 & 60 & ${ }_{30}$ \\
\hline \%ирні сорти птиці & - & $\frac{10}{10}$ & 40 & 50 \\
\hline Жирні сорти рнбй & - & $\because$ & 50 & 50 \\
\hline Какао & - & $\div$ & 20 & 80 \\
\hline 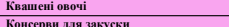 & $\therefore$ & 30 & 40 & 30 \\
\hline 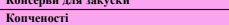 & & $x^{-}$ & 40 & $\frac{90}{60}$ \\
\hline Miциа кава & 10 & 30 & 10 & 50 \\
\hline М'ясиі көнсерви (тушона тощо) & & & 20 & 80 \\
\hline М'ясиі продукти (ковбаси тощо) & - & 40 & 30 & 30 \\
\hline Мариновані овочіi & - & 10 & 30 & 60 \\
\hline Мінеральна вода з великим вмістом $\mathrm{Na}$ & - & 20 & & 80 \\
\hline Рибопі консерви & - & ${ }^{-}$ & 20 & 80 \\
\hline 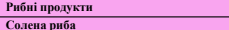 & $\therefore$ & & ${ }_{30}^{40}$ & 50 \\
\hline Соліния (помігори, огірки тощо) & $\cdot$ & 30 & 20 & 50 \\
\hline Тверді сири & & 30 & & 20 \\
\hline Хліб́ звичайної випічки & 90 & & 10 & \\
\hline Цибуля & 50 & 30 & 10 & 10 \\
\hline पасник & 10 & 20 & 40 & 30 \\
\hline Чорний хxіб & 50 & (n) & 20 & 30 \\
\hline $\begin{array}{ll}\text { ШІоколад } \\
\text { Шавель }\end{array}$ & & 30 & & $\frac{30}{100}$ \\
\hline
\end{tabular}

\section{Слайд 17}

Частота вживання заборонених при XXH продуктів харчування, жінки 70 років та старші, (\%)

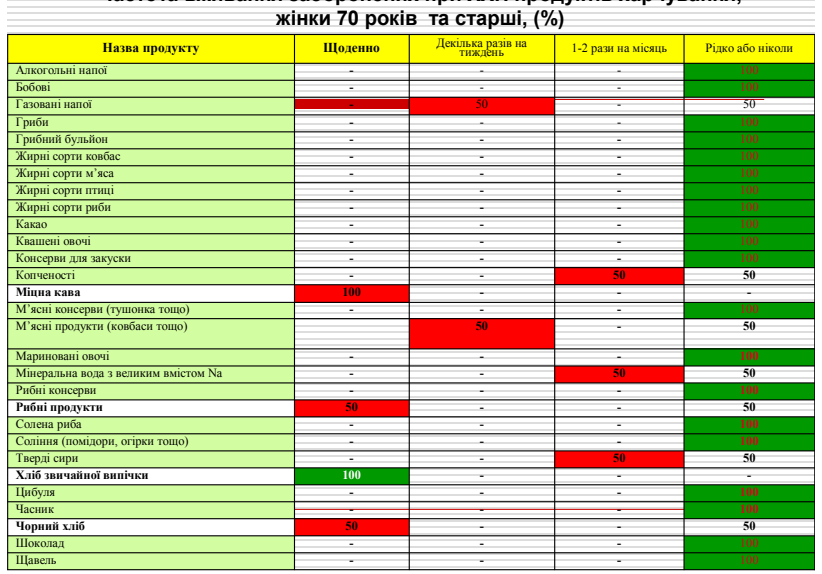

\section{Слайд 18}

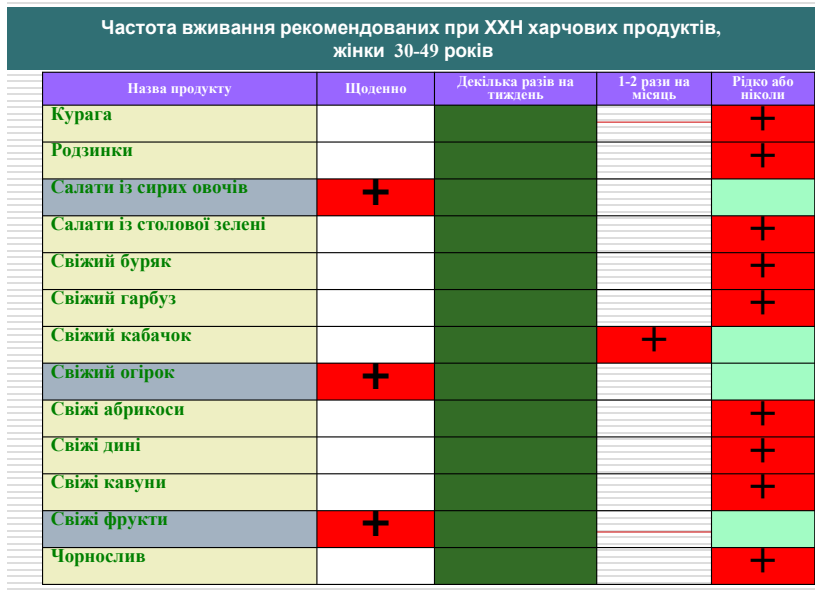




\section{Слайд 19}

Частота вживання рекомендованих при XXH продуктів харчування, жінки 70 років та старші, (\%)

\begin{tabular}{|l|c|c|c|c|}
\hline \multicolumn{1}{|c|}{ Назва продукту } & Щоденно & Декілька разів на тиждень & $\begin{array}{c}1-2 \text { рази на } \\
\text { місяць }\end{array}$ & $\begin{array}{c}\text { Рідко або } \\
\text { ніколи }\end{array}$ \\
\hline Курага & - & - & - & 100 \\
\hline Родзинки & - & - & - & 100 \\
\hline Салати із сирих овочів & 50 & - & 50 & - \\
\hline $\begin{array}{l}\text { Салати із столової } \\
\text { зелені }\end{array}$ & - & - & - & 100 \\
\hline Свіжий буряк & 50 & - & - & 50 \\
\hline Свіжий гарбуз & - & - & 50 & 50 \\
\hline Свіжий кабачок & 50 & - & 50 & \\
\hline Свіжий огірок & 50 & - & 50 & \\
\hline Свіжі абрикоси & 50 & - & - & 50 \\
\hline Свіжі дині & - & - & - & 100 \\
\hline Свіжі кавуни & - & - & 50 & 50 \\
\hline Свіжі фрукти & 50 & - & 50 & - \\
\hline Чорнослив & - & & - & 100 \\
\hline
\end{tabular}

\section{Слайд 20}

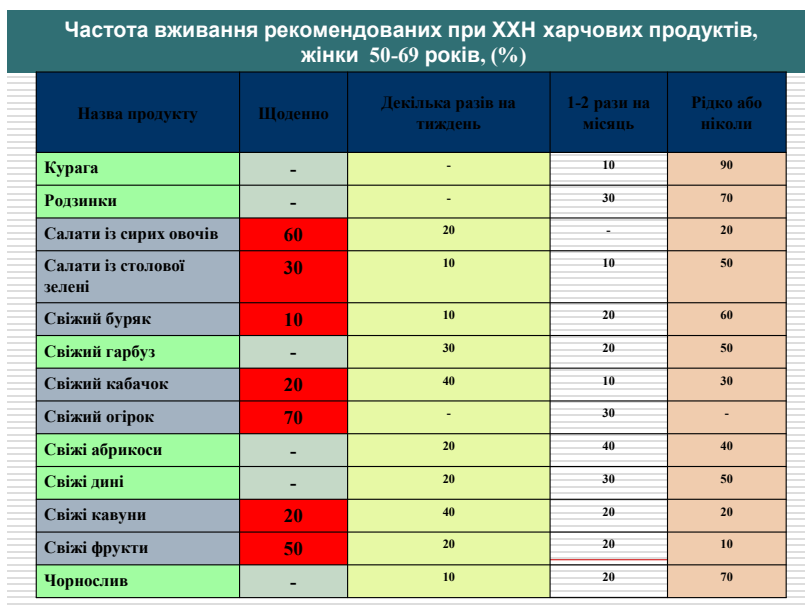

\section{Слайд 21} Для поліпшення харчового статусу пацієнтів на
хронічну хворобу нирок (XXН) та аліментарну
корекцію порушень необхідно:

\section{PEЗЮME}

\section{ОЦЕНКА ПИЩЕВОГО СТАТУСА У БОЛЬНЫХ ХРОНИЧЕСКОЙ БОЛЕЗНЬЮ ПОЧЕК И АЛИМЕНТАРНАЯ КОРРЕКЦИЯ ВЫЯВЛЕННЫХ НАРУШЕНИЙ}

Матасар И.Т., Алексеева Н.Г.

\section{(Киев)}

Введение. Данная работа посвящена проблеме недоедания у пациентов, которые лечатся диализом, также были описаны основные методы коррекции этого нарушения.

Цель. Установить нарушение пищевого статуса пациентов, находящихся на заместительной почечной терапии, перитонеальном диализе и разработать методики коррекции пищевого статуса.
Материалы и методы. У пациентов с хроническим заболеванием почек, которых лечат непрерывным диализом, определяют уровень калия, гемоглобина, альбумина и рассчитывают индекс массы тела (ИМТ), субъективную глобальную оценку (СГА). Корреляционный анализ был идентифицирован для того, чтобы определить долю пациентов с гипокалиемией и ее возможную связь с гемоглобином, альбумином, кальциево-фосфорным обменом, паратиреоидным гормоном, трансферрином, уровнями ферритина и ИМТ.

Результаты. В ходе обследования было установлено, что у пациентов с гипокалиемией уровень гемоглобина, альбумина и ИМТ ниже, чем у пациентов с нормальным уровнем калия в крови. Уровень трансферрина, ферритина, кальций-фосфорного обмена веществ, натрия и хлорида не имел существенных различий. Выводы. Корекция пищевого статуса боль- 
ных с почечной недостаточностью в сочетании с оптимизацией процедур диализа улучшает качество жизни больных.

Ключевые слова: хроническая болезнь почек, заместительная почечная терапия, состояние питания, недоедание, белково-энергетическая недостаточность.

\section{SUMMARY}

\section{ASSESSMENT OF FOOD STATUS IN CHRONIC PATIENTS KIDNEY DISEASE AND ALIMENTARY CORRECTION INSTALLED VIOLATIONS}

Matasar I.T., Alexeyeva N.G.

(Kyiv)

Introduction. This work is devoted to the problem of malnutrition in patients who are treated by peritoneal dialysis, also the main methods of correction this disorders were described.

The purpose. Identify malnutrition in patients undergoing renal replacement therapy or receiving peritoneal dialysis and develop nutritional status correction techniques.

Materials and Methods: In patients with chronic kidney disease, who are treated with continuous dialysis, the level of potassium, hemoglobin, albumin levels was determined and body mass index (BMI), subjective global assessment (SGA) was calculated. Correlation analysis was identify in order to get the proportion of patients with hypokalemia, and its possible connection with hemoglobin, albumin, calcium-phosphorus metabolism, parathyroid hormone, transferrin, ferritin levels and BMI.

Results: During the examination it was found that patients with hypokalemia have lower levels of hemoglobin, albumin and BMI than patients with normal levels of potassium in the blood. The level of transferrin, ferritin, calcium-phosphorus metabolism, sodium and chloride had no significant difference.

Conclusions. Correction of the nutritional status of patients with renal failure in combination with optimization of dialysis procedures improves the quality of life of patients.

Key words: chronic kidney disease, renal replacement therapy, nutritional status, malnutrition, protein-energy malnutrition.

\section{Матасар Ігнат Тимофійович} matasar.it@gmail.com 